\title{
GNAS NM_000516.5:C.478C>T
}

National Cancer Institute

\section{Source}

National Cancer Institute. GNAS NM 000516.5:c.478C>T. NCI Thesaurus. Code C146955.

A nucleotide substitution at position 478 of the coding sequence of the GNAS gene where cytosine has been mutated to thymine. 